\title{
CONCEPTUALISATION OF CULTURE PHENOMENA BY PRE-SERVICE TEACHERS OF FOREIGN LANGUAGES
}

\author{
Gerda Mazlaveckienė \\ Lithuanian University of Educational Sciences, Lithuania
}

\begin{abstract}
Cultural awareness has become the centre of modern language education that reflects a greater understanding of the inseparability of language and culture, as well as the need to train students for intercultural communication in the globalised world. Realising it or not, language teachers cannot avoid conveying impressions of another culture: language cannot be separated from the culture in which it is embedded. Therefore, while training a future teacher of a foreign language it is essential to develop his/her cultural awareness, i.e. the knowledge and understanding of the conventions, customs and beliefs of another culture, as well as abilities to interpret, relate and provide critical judgement of one's native and foreign cultures. Hence, the current article focuses on the conceptualisation of culture phenomena of pre-service teachers of foreign languages. It presents the results of a questionnaire survey conducted at five universities of Lithuania in 2014. The research sample involved 504 pre-service teachers of foreign languages (English, German, French, Polish and Russian), who completed a questionnaire survey consisting of both closed-ended and open-ended questions. The future teachers' conceptualisation of culture was analysed as twofold: perception and awareness of culture forms of the countries of the native and target languages, as well as their involvement in cultural activity.
\end{abstract}

Keywords: Culture, culture form, culture phenomenon, conceptualisation, pre-service teachers of foreign languages.

\section{Introduction}

Over thousands of years, the humanity has created and developed a large number of culture forms, each of which is closely related to its creator - a human being, nation, society - in terms of space and time. The development and functioning of culture forms defines the social ways of human activity that embraces material objects (things, articles, works, etc. created by humans) and spiritual aspects (systems of values, behaviour norms, ideals, beliefs and others) (Andrijauskas, 2006; Giddens et al., 2014; Halloran \& Kashima, 2011; Thanasoulas, 2001 and others). It is hardly surprising that due to the versatility of its meanings, the conception of culture has become one of the most complicated in the system of different sciences. 
The multidimensionality of the culture concept was first revealed in the works of American anthropologists A. L. Kroeber (1989) and C. Kluckhohn (1962). They provided over 300 different definitions of culture. Consequently, it is possible to speak about 300 different interpretations of the concept of culture. Generally speaking, culture is perceived as an indicator of an individual's maturity, the area of the expression and implementation of his/her creative and spiritual powers, as well as an individual sphere of human life and activity. Moreover, culture is also viewed as an aggregate of the achievements of the society that is manifested and evaluated in all the spheres of social life (Mazlaveckienè, 2015).

However, the rapid processes of globalisation, as well as its resulting consequences, such as mass migration and diversity of political, economic, cultural, linguistic, educational and other processes pose numerous challenges on humanity. Exploring the consequences of globalisation on the development of humanity, researchers of Lithuania and the world focus on cultural changes in particular (Andrijauskas, 2006; Bauman, 2007; Gudykunst, 2002; Kundrotas, 2009; Kuzmickas, 2003; Lang \& Lang, 2009 and others). Due to the establishment of the notion globalisation, the culture concept also undergoes major changes: over the past few decades such terms as global culture, interculture, cross-culture, one-world culture, multiculturalism and others have been used. All of them refer to cultural equality opt out of geographical, historical and national differences and permit all nations to perform on the international arena on an equal basis. In the last decades of the 20th century, national cultures were perceived as individual islands, whereas the world was considered as a mosaic of those islands. However, globalisation processes have revealed that homogeneous culture groups do not exist any longer; they have been changed by heterogeneous groups: 'Culture in this sense is perceived not as a static, hermetically sealed system, but as a current of ever changing meanings' (Deardorff, 2004, p. 6). Hence, culture is a dynamic process, which embraces norms, values and lifestyles, which are globally intertwined.

Such a changed approach to the conceptualisation of culture sets new objectives to teaching and learning of foreign languages. In Lithuania, the regulatory documents on Education highlight the following aims: to develop lifelong cultural competence and creativity of a human being (Guidelines for Cultural Policy of Lithuania, 2010), to strive that every person shall become a member of the national and global community, advanced economy and a particular national culture (State Education Strategy for 2013-2020, 2012), to develop cultural awareness and expression (Education and Training 2020), to convey to a person the basics of national and ethnic culture, the traditions and values of the humanistic culture of Europe and of the world, to foster the maturation of a person's national identity, moral, aesthetic and scientific culture as well as 
personal outlook; to guarantee the continuity of ethnic and national culture, the preservation of its identity and continuous renewal of its values; to promote the country's openness and inclination for dialogue (Law on Education of RL, 2011) and others.

The topicality of cultural education is strengthened in the National Description of Teacher Competences (2007), where the common cultural competence is distinguished and defined as "knowledge, skills, abilities, valuebased provisions and other personal qualities determining human activity in specific cultures" (National Description of Teacher Competences, 2007, p. 1). Teachers form a community of lifelong learners that are expected to continuously expand their subject-specific knowledge, participate in cultural and political life, broaden their general cultural world outlook, as well as "help the learners acquire cultural knowledge and awareness, develop abilities and attitudes essential to understand, acknowledge, respect and participate in transferring the cultural values of different persons, nations and races, as well as to develop own skills of cultural expression" (Integrated Programme of Cultural Awareness, 2008). Hence, a teacher's position undergoes certain changes as well. The teacher, especially the one of foreign languages, becomes a 'teacher of culture' and is ascribed new tasks: his/her attention should focus on the development of students' attitudes, skills and critical cultural awareness rather than mere transfer of subject knowledge. In other words, a teacher of a foreign language is expected to develop students' cultural awareness, which would encourage them to link and compare own cultural values, attitudes and behaviour with other cultures.

Hence, the problem of the research is formulated as a question: How do pre-service teachers of foreign languages conceptualise the phenomena of the native and target cultures?

The object of the research is the conceptualisation of culture phenomena of pre-service teachers of foreign languages.

The aim of the research is to disclose the ways of how pre-service teachers of foreign languages conceptualise the cultural phenomena of their native and target cultures.

The objectives of the research are as follows:

1) To determine the ways of how pre-service teachers of foreign languages perceive the types and specific phenomena of culture;

2) To reveal their culture-related experience and attitudes;

3) To evaluate the level of their cultural awareness of the native culture and the culture of the studies foreign language. 
Gerda Mazlaveckiene. Conceptualisation of Culture Phenomena By Pre-Service Teachers of Foreign Languages

\section{Methodology}

The following research methods were employed in the current research:

Theoretical: analysis of scientific literature on culture and cultural education;

Empirical methods: a questionnaire survey, including open-ended and closed-ended questions, which helped to reveal the level of the conceptualisation of culture phenomena by pre-service teachers of foreign languages;

Statistical methods: the research data were processed using Statistical Package for Social Sciences (SPSS) 17.0.

The research sample. The research was conducted as a part of doctoral research in spring-autumn 2014 and involved 504 pre-service teachers of foreign languages (English, German, French, Polish and Russian) of the five largest Lithuanian universities: Lithuanian University of Educational Sciences, Vilnius University, Šiauliai University, Vytautas Magnus University and Klaipėda University. The sample was considered to be reliable. According to the data provided by the Department of Statistics of the Republic of Lithuania, 1622 students studied in the study programmes of foreign language philology, seeking for the qualification of a foreign language (English, German, French, Russian or Polish) teacher. The confidence interval being $5 \%$, the confidence level is $95 \%$ (Paniotto \& Maksimenko, 2003). Hence, the research sample should have involved 320 respondents.

The total sample included $83.5 \%$ of females $(n=421)$ and $16.5 \%$ of males $(\mathrm{n}=81)$. Such a big discrepancy occurred due to the study preferences of the youth: languages are mostly preferred by females rather than by males.

According to the distribution of the year of studies, the sample split fairly equally: $30.8 \%$ of first-year students $(\mathrm{n}=155), 25.6 \%$ of second-year students $(\mathrm{n}=129), 26.8 \%$ of third-year students $(\mathrm{n}=135)$ and $16.9 \%$ of fourth-year students $(\mathrm{n}=85)$ that intended to become teachers of foreign languages. The number of fourth-year respondents was smaller than the remaining three groups of the sample, which was conditioned by a larger number of drop-outs incurred in the previous three years of studies.

Research tool. Seeking to explore how pre-service teachers of foreign languages conceptualised culture phenomena, a questionnaire embracing closedended and open-ended questions was designed. It covered items related to preservice teachers' awareness of the forms of culture and specific culture phenomena, involvement in culture-related activities, reflection of the gained cultural experience, as well as demographical data of the respondents. The paper versions of the questionnaire were distributed to future teachers of foreign languages of five Lithuanian universities personally by the author of the article. 


\section{Research Findings}

Culture is a very broad concept, so to get to know a given culture means to gain extensive knowledge and awareness of it. Hence, seeking to explore preservice teachers' awareness of cultural phenomena, four main types of culture and their main properties were distinguished: elite (or high culture), ethnic, popular culture and subcultures.

Elite (high) culture is often attributed to aristocracy or upper social class, which is characterised as the ruling culture, which should be observed by every person, or a privileged culture marked by peculiar spiritual, economic, political and other properties (The Europe of Elites, 2012). On the other hand, elite (or high) culture embraces world-famous and acknowledged works of art, as well as achievements in sports and science (Andrijauskas, 2006; Gaižutis, 2008; Lang \& Lang, 2009).

Ethnic culture comprises a wide variety of aspects, many of which are interconnected, including attitudes, assumptions, beliefs, perceptions, norms and values, social relationships, customs, celebrations, rituals, politeness conventions, patterns of interaction and discourse organisation, the use of time in communication and other aspects characteristic of a particular nation or country. This form of culture involves such phenomena as folk myths, rituals, customs, oral, musical and visual heritage, which are determined by common history, territory, race and language (Andrijauskas, 2006; Bukraba-Rylska, 2002; Fiske, 2008).

Popular culture largely concentrates on the stereotypes of mass consciousness, seeking to imitate celebrities, satisfy hedonistic needs, conform to the changing conditions and abandon own individuality and distinction. Consumer art, fashion and entertainment are attributed to this type of culture (Andrijauskas, 2006; Brooks, 2014; Fiske, 2008).

Moreover, modern society breaks down into individual groups that have a peculiar culture, repudiate the prevailing norms and create alternative approaches to different aspects of life, including identity, religion, society and others. Subcultures involve independently functioning groups, which choose different stylistic forms to express their individuality and distinctness. They are often defined as either a highly educated part of society formed as a result of professional differentiation, or a completely uneducated marginal group (Andrijauskas, 2006; Ramanauskaite, 2004).

Seeking to explore the level of the awareness, the pre-service teachers of foreign languages were supplied with a list of randomly ordered culture phenomena and asked to attribute them to an appropriate type of culture. The frequency of the replies of the respondents is presented in Table 1. 
Gerda Mazlaveckiene. Conceptualisation of Culture Phenomena By Pre-Service Teachers of Foreign Languages

Table 1 Distribution of the respondents' replies according to their recognition of the phenomena of main culture types

\begin{tabular}{|l|c|c|c|c|}
\hline \multicolumn{1}{c}{$\begin{array}{c}\text { Type of } \\
\text { culture }\end{array}$} & Elite & Ethnic & Popular & Subculture \\
\cline { 2 - 5 } Phenomenon & $\begin{array}{c}\text { Correct } \\
\text { answers (\%) }\end{array}$ & $\begin{array}{c}\text { Correct } \\
\text { answers (\%) }\end{array}$ & $\begin{array}{c}\text { Correct } \\
\text { answers (\%) }\end{array}$ & $\begin{array}{c}\text { Correct } \\
\text { answers (\%) }\end{array}$ \\
\hline Phenomenon 1 & 63.1 & 67.3 & 14.1 & 18.1 \\
\hline Phenomenon 2 & 37.1 & 81.0 & 67.7 & $\mathbf{6 8 . 8}$ \\
\hline Phenomenon 3 & 76.6 & 81.7 & 68.5 & 54.6 \\
\hline Phenomenon 4 & $\mathbf{8 9 . 1}$ & $\mathbf{8 9 . 7}$ & 56.7 & 62.7 \\
\hline Phenomenon 5 & 32.5 & 52.6 & $\mathbf{7 7 . 4}$ & 58.9 \\
\hline The mean: & $\mathbf{5 9 . 6 8}$ & $\mathbf{7 4 . 4 6}$ & $\mathbf{5 6 . 8 8}$ & $\mathbf{5 2 . 5 8}$ \\
\hline
\end{tabular}

The evaluation of the respondents' replies was based on the following ranking: $76-100 \%$ of the correctly attributed phenomena showed that the preservice teachers demonstrated high level of the awareness of culture phenomena; $51-75 \%$ of correctly attributed phenomena were considered as above the average level; $26-50 \%$ and $0-25 \%$ were regarded as average and low levels of awareness respectively.

The analysis of the research data revealed that the respondents' level of the awareness of culture phenomena was above average, since they managed to attribute more that $50 \%$ of all the phenomena to appropriate culture types. It appeared that the pre-service teachers were best aware of ethnic culture (they succeeded in attributing nearly three quarters $(74.46 \%)$ of the outlined phenomena correctly). The respondents demonstrated the poorest awareness of subcultures (they correctly attributed $52,58 \%$ of the outlined phenomena).

In order to assess the level of the respondents' conceptualisation of culture phenomena, they were asked to choose two types of culture and define them by distinguishing their main properties. The frequency of their choice is presented in Figure 1. 


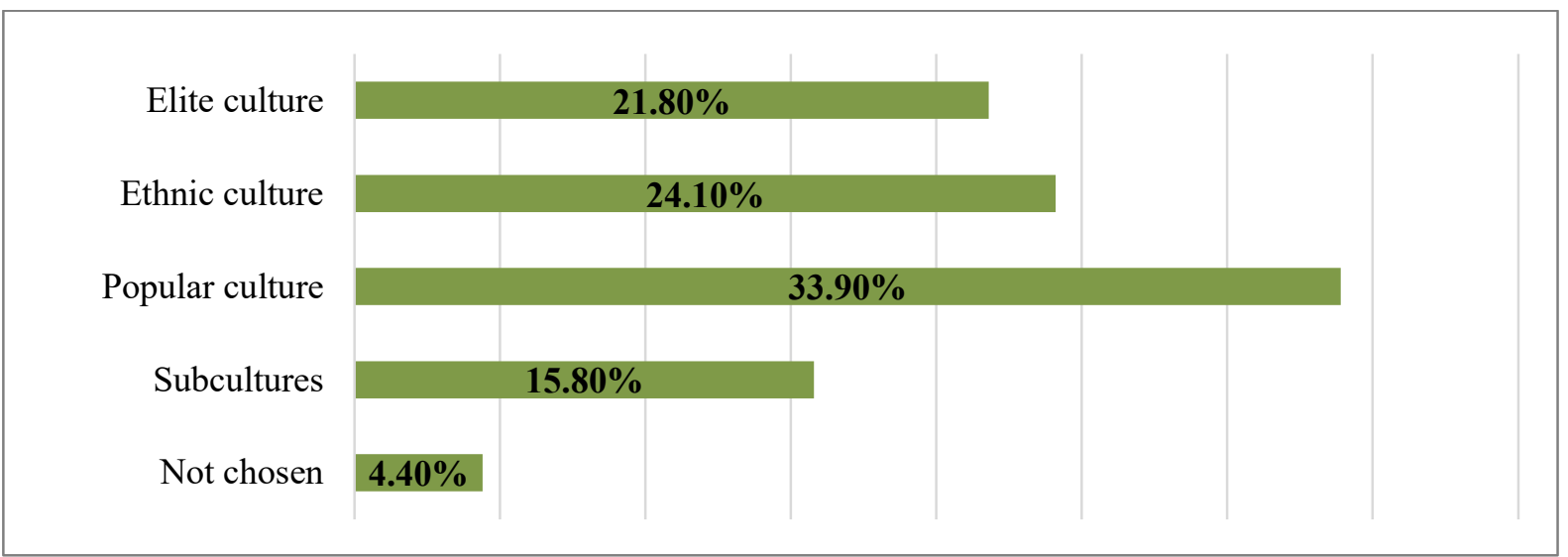

Figure 1 Distribution of the respondents according to the choice of a culture form

The comparative analysis of the obtained data demonstrated that the respondents most often selected those culture types, which they managed to recognise by attributing the outlined culture phenomena. Hence, the pre-service teachers of foreign languages most frequently chose to define popular (over a third of the respondents) and ethnic (about a quarter of the respondents) culture types. The rarest choice was made for subcultures: only $15.8 \%$ of the respondents preferred defining it. It is obvious that the pre-service teachers of foreign languages believed that they were best aware of popular culture.

Moreover, the level of the conceptualisation of culture phenomena was also evaluated by analysing the quality of the provided definitions. They were assessed in terms of four ranks: 1) the respondents distinguished 4-5 characteristic properties of the selected type of culture that revealed their good awareness of the selected culture phenomena; 2) the respondents distinguished 2-3 properties which revealed their sufficient awareness of the selected type of culture; 3 ) the provided definition did not comply or only partially complied with the selected culture type, which showed superficial awareness of culture phenomena; 4) no definition was provided, which was considered as a lack of awareness of the culture types. The frequency of the choice is provided in Fig. 2.

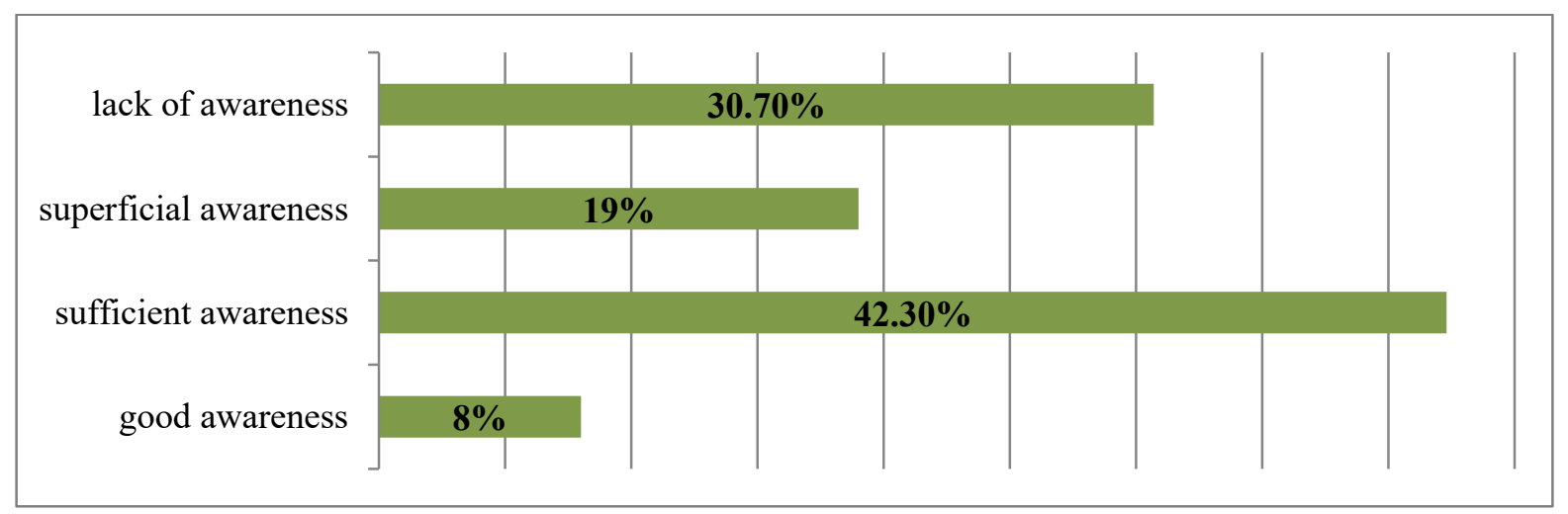

Figure 2 Distribution of the respondents in terms of the quality of the provided definitions of a selected culture form 
As it is seen from Figure 2, the pre-service teachers of foreign languages tended to define the selected culture forms by distinguishing 2-3 minor properties of the selected culture form ( $42.3 \%$ of the respondents). It is noteworthy that approximately a third of the respondents $(30.7 \%)$ demonstrated their inability to conceptualise a culture type, whereas a fifth provided definitions incompliant with the selected type of culture. It should be pointed out that the pre-service teachers succeeded in conceptualising popular culture best of all. According to them, popular culture is mostly related to consumerism, imitation, the power of the media, as well as popular music, literature and film, which are considered as key properties of popular culture (Fiske, 2008).

According to some researchers (Helmke, 2012; Jakubè \& Juozaitis, 2012; Petty, 2008; Pollard, 2002), reflection of own attitudes and experience create preconditions for a person to construct and try out new models of behaviour in new situations; therefore, experience should bear personal meaning to the learners themselves. Only then will it encourage them for further development. Hence, in order to determine the level of the conceptualisation of culture-related experience, attempts were made to discover what factors were considered by the pre-service teachers of foreign languages as having the greatest impact on their cultural development. The obtained results are presented in Figure 3.

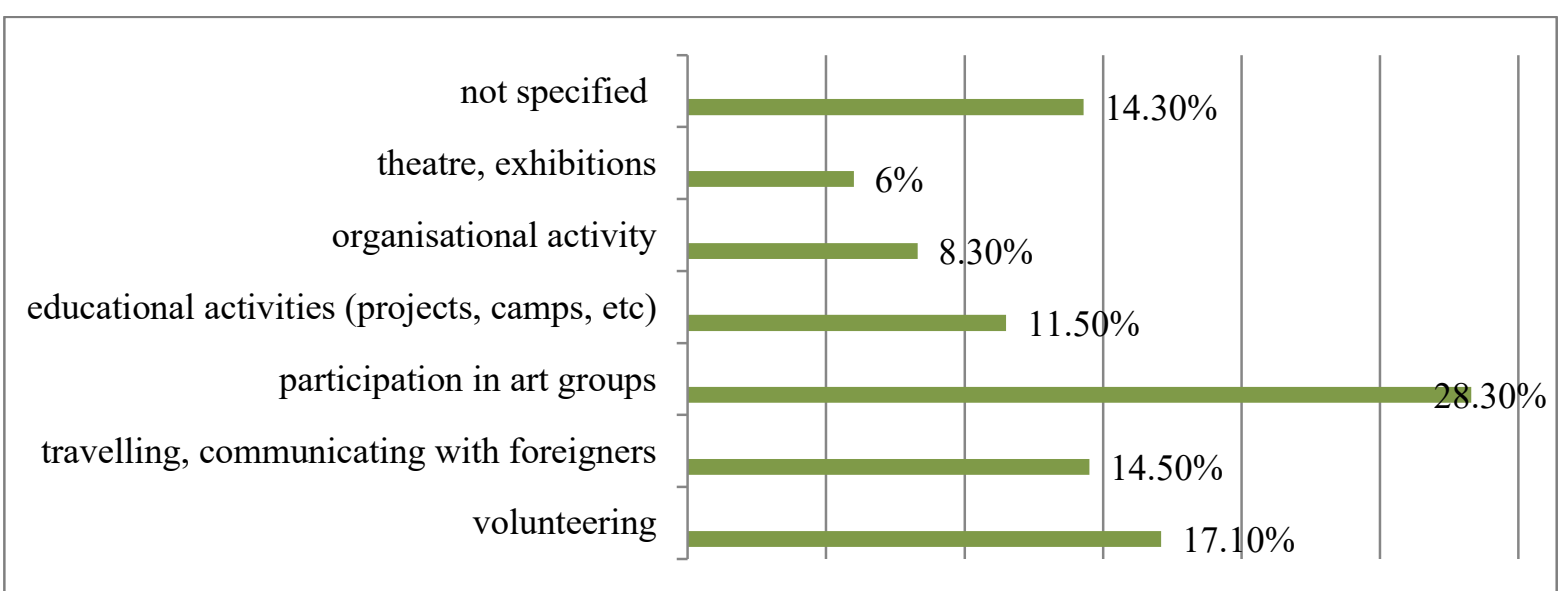

Figure 3 Distribution of the respondents in terms of the experience gained in culturerelated activities

The data analysis revealed that $14.3 \%$ of the respondents did not specify any activities significant for the acquisition of experience, or these activities were not culture-related. The most significant activities that were indicated by the preservice teachers of foreign languages included participation in art groups (28.3 $\%$ ), volunteering $(17.1 \%)$, and travelling and communication with representatives of other cultures $(14.5 \%)$. Among the groups of art, the pre-service teachers of foreign languages ( $80 \%$ of the ones who chose this option) most frequently 
indicated folk music and dance ensembles, which showed that a great part of the respondents actualised their cultural self-expression in the context of ethnic culture. It is noteworthy that the manifestations of elite culture (attending art exhibitions, theatre, museums, etc.) was not conceptualised by the pre-service teachers of foreign languages as significant activities developing their cultural experience (only $6 \%$ of the respondents considered this aspect as an important culture-related activity).

The significance of cultural activity is closely related to the attitudes that accompany the activity, which transform the perception of the activity itself and relate it to former knowledge and information (Bubnys \& Žydžiūnaite, 2012). Therefore, the pre-service teachers of foreign languages were asked to describe the attitudes that they related to the afore-said experience of being involved in culture-related activities. Their attitudes were grouped into positive, negative and indifferent (see Figure 4).

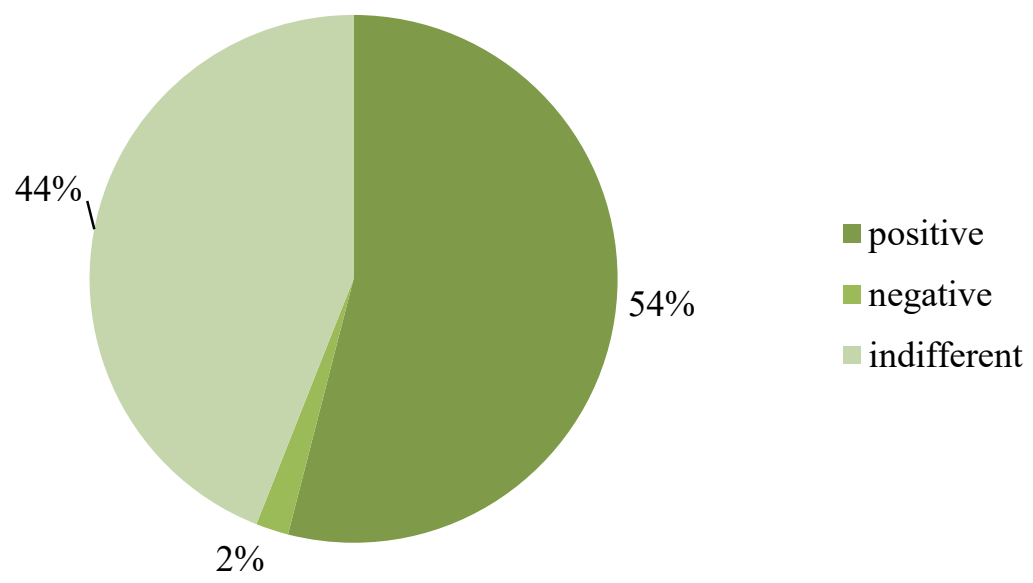

Figure 4 Distribution of the respondents according to the attitudes related to cultural experience

The data analysis revealed that more than a half of the respondents had a positive attitude to their cultural experience. It should be noted that $2 \%$ of the pre-service teachers indicated a negative attitude, whereas as far as $44 \%$ did not conceptualise their attitudes at all. A deeper analysis demonstrated that the positive attitudes were mostly associated with the feelings of joy and happiness (34\% of the respondents), responsibility for own activity (27.8\%) and pride in own achievements $(14.6 \%)$. The negative ones were most often related to the feeling of shame, which occurred due to the lack of awareness of how to behave in a particular situation $(2 \%)$.

Summing up, it can be stated that the level of the respondents' conceptualisation of culture-related experience is not high: a relatively big part of future teachers of foreign languages $(14.3 \%)$ were unable to evaluate their 
Gerda Mazlaveckiene. Conceptualisation of Culture Phenomena By Pre-Service Teachers of Foreign Languages

cultural experience as having an impact on their cultural development. Moreover, almost a half of the respondents $(44 \%)$ could not conceptualise their attitudes towards the gained cultural experience.

\section{Discussion}

The analysis of the research works conducted by Lithuanian and foreign authors (Deardorff, 2004; Kohli et al., 2010 and others) reveals that an important precondition for teaching/learning a foreign language is the awareness of the target culture, its values and characteristic phenomena. Therefore, seeking to train specialists of foreign languages, it is important to develop their cultural awareness. In our research, we employed the provisions of the afore-said authors to explore the cultural awareness of pre-service teachers of foreign languages and their ability to conceptualise the phenomena of the target culture as compared to their native culture.

Analysing the intercultural competence of future social workers (Kohli et al., 2010), students in higher education and school management (Deardoff, 2004), the researchers determined that cultural behaviour was directly dependent on the knowledge and awareness of the target culture and its specific phenomena. The findings of the current research demonstrated that the level of the awareness of cultural phenomena of pre-service teachers of foreign languages was slightly above average. Moreover, the respondents experienced relative difficulty in conceptualising their culture-related experience and attitudes. It is assumed that the lack of knowledge and awareness of the types of culture and their characteristic phenomena results in their poor ability to conceptualise their culture-related experience and attitudes.

It has also been proved that students develop their cultural awareness when they are constantly encouraged to reflect on own experience. This way, they learn to assume responsibility for own behaviour and its consequences in different culture-related situations (Bubnys \& Žydžiūnaitè, 2012; Helmke, 2012; Pollard, 2002; Railienè, 2010; Riel, 2010). The findings of our research lead to the assumption that pre-service teachers of foreign languages are not used to reflecting on own culture-specific knowledge, experience and attitudes.

\section{Conclusions}

On the basis of the conducted research, it can be stated that the level of the conceptualisation of culture phenomena of pre-service teachers of foreign languages rather average. Only a half of the respondents are able to distinguish and conceptualise main culture types by identifying their key properties. The best known and conceptualised culture form is ethnic culture $(74.46 \%)$, which is 
largely related to mother tongue, traditional customs and traditions, feasts and rituals. Another culture forms that is conceptualised by the respondents is popular culture $(56.88 \%)$, which is associated with popular music, cinema, media, consumerism and imitation.

A far as the conceptualisation of culture-related experience is concerned, it appears that, similarly to the conceptualisation of culture forms, it is of mediocre level. $14.3 \%$ of the pre-service teachers of foreign languages are hardly able to conceptualise own cultural experience. The data analysis demonstrates that volunteering, participation in the activity of art groups (mainly folk music and dance ensembles), as well as travelling and communicating with representatives of other cultures are considered as the most significant activities actualising the respondents' cultural self-expression. However, it turns out that only $46 \%$ the future teachers of foreign languages are able to conceptualise their attitudes related to this experience.

\section{References}

Andrijauskas, A. (2006). Technogeninè civilizacija, medijos ir kultūros globalizacija. Kultürologija 13. Kultūra globalizacijos salygomis. Vilnius: Kultūros, filosofijos ir meno institutas, 76-96.

Bauman, Z. (2007). Globalizacija: pasekmès žmogui. Vilnius: Apostrofa.

Brooks, A. (2014). Popular Culture: Global Intercultural Perspectives. Palgrave Macmillan.

Bubnys, R., \& Žydžiūnaitè, V. (2012). Reflektyvusis mokymas(is) aukštosios mokyklos edukacineje aplinkoje: dèstytoju mokymo patirtys. Šiauliai: Lucilijus.

Bukraba-Rylska, I. (2012). Kultura na wsi: folklor, uczestnictwo czy praktyki kulturowe. In A. Rosner (ed.) Spoleczne i kulturowe zagadnienia przemian na wsi polskiej. Warszawa: IRWIR PAN.

Deardorff, D. K. (2004). The Identification and Assessment of Intercultural Competence as a Student Outcome of Internationalization at Institutions of Higher Education in the United States [Doctoral dissertation]. Retrieved from http://repository.lib.ncsu.edu/ir/ bitstream/1840.16/5733/1/etd.pdf

Education and Training 2020 (2012). Retrieved from http://www.europarl.europa.eu/sides/ getDoc.do?pubRef=-//EP//NONSGML+TA+P7-TA-2012-0323+0+DOC+PDF+V0//LT

Fiske, J. (2008). Populiariosios kultūros supratimas. Vilnius: Žara.

Gaižutis, A. (2008). Daugiaveidis elitas. Vilnius: Vilniaus pedagoginio universiteto leidykla.

Giddens, A. et al. (2014). Introduction to Sociology. New York, London: W. W. Norton and Company, Inc.

Gudykunst, W. B. (2002). Intercultural Communication Theories. In Cross-cultural and Intercultural Communication. Thousand Oaks: Sage Publishers, 167-189.

Guidelines for Cultural Policy of Lithuania (2010). Retrieved from https://eseimas.lrs.lt/portal/legalAct/lt/TAD/TAIS.377620.

Halloran, M. J., \& Kashima, E. S. (2011). Culture, Social Indentity and the Individual. In Individuality and the Group: Advances in Social Identity. London: Sage Publishing Ltd.

Helmke, A. (2012). Pamokos kokybe ir mokytojo profesionalumas: diagnostika, vertinimas, tobulinimas. Vilnius: Nacionalinè mokyklų vertinimo agentūra. 
Gerda Mazlaveckiene. Conceptualisation of Culture Phenomena By Pre-Service Teachers of Foreign Languages

Integrated Programme of Cultural Awareness (2008). Retrieved from www.upc.smm.lt/ suzinokime/bp/failai/11_priedas_iju_ugdymas.doc

Jakubè, A., \& Juozaitis, A. M. (2012). Bendrujų kompetenciju ugdymas aukštojoje mokykloje. Vilnius: Vilniaus universiteto leidykla.

Kohli, K. H., Kohli, A. S., Huber R., \& Faul, A. C. (2010). Assessing Cultural Competence in Graduating Students. International Journal of Progressive Education, 6 (1), 6-27.

Kluckhohn, C. (1962). Culture and Behavior: The Collected Essays of Clyde Kluckhohn. Free Press.

Kroeber, A. L. (1989). Istota kultury. Warszawa: Panstwowe Wydawnictwo Naukowe.

Kundrotas, M. (2011). Pasaulinio identiteto gairès. In Individas, tauta ir visuomene postmoderniame pasaulyje: ekonominès ir socialinés politikos studijos (VIII). Vilnius: VPU leidykla.

Kuzmickas, B. (2003). Globalizacija - priklausomybès ir tapatybės. In J. Morkūnienė (ed.). Globalizacija: taikos kultūra, žiniu visuomené, tolerancija: monografija. Vilnius: Lietuvos teisès universitetas, 30-42.

Lang, K., \& Lang, G. E. (2009). Mass Society, Mass Culture and Mass Communication: the Meaning of Mass. International Journal of Communication, 3, 998-1024.

Law on Education of RL (2011). Retrieved from http://planipolis.iiep.unesco.org/upload/ Lithuania/Lithuania_Law_amending_Law-on-education_2011.pdf

Mazlaveckienè, G. (2015). Kultūros samprata: ištakos $\overline{\text { ir }}$ šiuolaikiniai laukai. In E. Martišauskienė (ed.). Edukologijos inžinerijos link: teorijos ir praktikos sanglauda. Vilnius: Lietuvos edukologijos universiteto leidykla.

National Description of Teacher Competences (2007). Retrieved from https://eseimas.lrs.lt/portal/legalAct/lt/TAD/TAIS.291726

Petty, G. (2008). Irodymais pagristas mokymas: praktinis vadovas. Vilnius: Tyto alba.

Pollard, A. (2002). Refleksyvusis mokymas: veiksminga ir duomenimis paremta profesine praktika. Vilnius: Garnelis.

Railienè, A. (2010). Profesijos patarejo kompetenciju ugdymas rengiant socialinius pedagogus [doctoral dissertation]. Vilnius: Vilniaus pedagoginis universitetas.

Ramanauskaitè, E. (2004). Subkultūra: fenomenas ir modernumas: XX a. pabaigos Lietuvos subkultūriniu bendrijų tyrinëjimai. Kaunas: Vytauto Didžiojo universiteto leidykla.

Riel, M. (2010). Understanding Action Research, Center For Collaborative Action Research, Pepperdine University (Last revision Sep, 2013). Retrieved from http://cadres.pepperdine.edu/ccar/define.html.

State Education Strategy 2013-2020 (2012). Retrieved from https://rio.jrc.ec.europa.eu/en/ library/state-education-strategy-2013-2022.

Thanasoulas, D. (2001). The Importance of Teaching Culture in the Foreign Language Classroom. Radical Pedagogy, 3/7.

The Europe of Elites: A Study into the Europeanness of Europe's Political and Economic Elites (ed. by Best H., Lengyel G., Verzichelli L.) (2012). Oxford University Press.

Паниотто, В. И., \& Максименко, В.С. (2003). Количественные методы в социологических исследованиях. Retrieved from www.socioline.ru/node/395 